William E. Landis

\title{
Personas and Archetypes: Envisioning the 21st-Century Special Collections Professional
}

PERSONAS, AS USED IN THE WORLD of information architecture and user experience design, represent an archetype. ${ }^{1}$ They capture, in a narrative format, a composite of goals, attitudes, skills, behaviors, frustrations, environmental factors, and work or activity flows of a range of actual people represented by the archetypal persona. Of course, in a user experience design setting, personas are based on qualitative and quantitative data gathered from observing and interacting with end-user populations envisioned for the service or interface being designed. Using personas helps Web designers and information architects avoid pitfalls such as overly elastic conceptions of the real people who will use what they are designing, or too much self-reference in their designs, or designing too generic an interface or service to be useful to actual end users. ${ }^{2}$

The California Digital Library $(\mathrm{CDL})^{3}$ is a unit of the University of California Office of the President charged with leveraging the common needs of ten campuses in licensing digital library resources, building digital content, and developing technical infrastructures for the preservation of, and access to, digital content. CDL has assessment and user experience design teams who have developed a series of personas for targeted end-user communities for CDL products and services. ${ }^{4} \mathrm{Wan}$ -

1. I wish to thank my CDL colleagues Robin Chandler, for the initial idea of using personas to frame this topic, and Lena Zentall, for leadership and enthusiasm about personas at CDL.

2. The concept of personas as a tool for goal-directed software interface design was introduced by Alan Cooper in The Inmates Are Running the Asylum (Indianapolis: SAMS Publishing, 1999). There is currently somewhat of a cottage industry surrounding the use of personas for interface design, as evidenced by the diverse Web literature on the application of personas in a variety of technology settings. See, for example, John Pruitt and Jonathan Grudin, "Personas: Practice and Theory" (2003), available at http: / / portal.acm.org/ citation.cfm?id=997089; Tina Calabria, "An Introduction to Personas and How to Create Them" (Mar 2, 2004), available at http:/ / www.steptwo.com.au/papers/kmc_personas/; and Bryan Eisenberg, "Persona Development and the Law of Averages" (Jan. 14, 2005), available at http:// www.clickz.com/experts/crm/traffic/print.php/3457531. All cited URLs accessed on 28 August 2005.

3. More information about the CDL and its projects, products, and services is available at http:// www.cdlib.org. Accessed on 28 August 2005.

4. As one example, see the American West project personas (Apr. 12, 2005) at http:/ / www.cdlib. org/inside/projects/amwest/\#minutes. Accessed on 28 August 2005. 
der into any CDL conference room, and you'll see the names and photographs of, and information about, these personas on the walls, serving as a constant reminder to CDL staff that we go about our daily activities in service of real people with real needs for information resources. Despite some healthy skepticism when the CDL personas were unveiled early in 2005 , they have proved quite effective in focusing attention on needs articulated by end users in a variety of CDL assessment activities over the course of several years and in building consensus around something other than the opinions of individual members of a sometimes mind-numbing number of project teams at work at CDL.

You may be wondering why I've chosen to frame my remarks on educating special collections professionals using the concept of personas. All of us know that special collections repositories are anything but monolithic. This enormously complicates the question of the kinds of educational opportunities and concentrations that would be of the most benefit to students in graduate programs hoping to find gainful professional employment in an academically oriented special collections repository. Now complicate that even further by trying to envision where special collections in an academic library setting are headed over the next fifty, or even twenty-five, years. It should not be much of a stretch for today's special collections professionals to envision that even in twenty years, our successors will be doing some things that are remarkably similar to, but also some that are remarkably and perhaps surprisingly different from, what we do today. What is that mixture of stasis and change likely to be? How is it likely to be different for those working in large, renowned research institutions than it is for those working in small undergraduate-focused colleges? Or for those working at maintaining, expanding, and promoting the use of long-standing collections with international significance versus those working to develop collections whose importance is primarily to local communities, both gown and town?

One challenge in thinking about core competencies and professional education programs at any point in time, but especially in the present, volatile technical world of the information and communication professions, is to figure out a creative way to avoid constraining future possibilities with too narrow a focus on the past and present. Surely the competencies we define today will play a role in steering (or not) creative new talent into our particular neighborhood of those information professions. Putting the challenge another way, we need to keep the education of new special collections professionals grounded in the current realities of a wide variety of institutions, while at the same time articulating a vision of the kinds of expertise and leadership needed to ensure a broad spectrum of vibrant, engaged, relevant, and busy academic special collections repositories in 2020, or 2050. 
The primary goal of this article is to suggest that using personas may be a successful tactic for keeping the conversation about core competencies for special collections professionals at a usefully broad level, one not grounded in the ideas and realities of individuals participating in that conversation. Approaching personas in this way represents a bit of a departure from how they are currently used in the Web design community. Because we would be trying to envision the skills, interests, and daily routines of our professional colleagues twenty or fifty years hence, we cannot, as interface designers would, base our personas on data gathered from that targeted group.

Instead, it seems feasible to identify a representative sample of current institutional types and of roles within those institutions, and from that group solicit short, structured narratives envisioning an ideal professional colleague in 2020. That colleague could be someone who plays a role similar to that which the writer plays within her or his institution today. In what ways would a few days in that colleague's life be similar to and different from ours today? We also might profitably solicit contributions from people outside the pool of currently active special collections professionals who are important stakeholders for us, including academic library directors and faculty who actively use special collections resources for research and teaching. The former might envision the kind of special collections director they would like to have as part of their administrative team in 2020, and the latter might speculate on the ideal person interacting in 2020 with his or her undergraduate students who are learning to conduct original research weaving together primary and secondary sources.

From a healthy, broadly representative number of such short, structured narratives, it seems quite feasible that several helpful archetypal personas for special collections professionals twenty to thirty years from now could be derived. Such a suite of composite personas could support an innovative, lively consideration about core competencies and educational needs for both graduate professional and postappointment continuing education. These personas may help us understand, in 2006, the kinds of educational opportunities for graduate students and current professionals that should ideally be made available within the next five to fifteen years.

In an attempt to give you a better sense of how one individual contribution to this effort might look, I want to spend a bit of time introducing you to Rana Ariza. We're in the year 2020, a year I've chosen because it seems not so close to the present, yet not unrealistically distant; a year, in short, when, if I'm lucky, I might actually be starting to think about retirement.

Rana Ariza is a professional colleague of mine in a large and relatively prestigious state research university with about 24,000 undergraduates and 9,000 graduate stu- 
dents. She works in special collections and is responsible for coordinating all public services operations and for collection development, primarily in a regionally significant collection of archival records and ephemeral publications from individuals, community groups, and businesses. I served as a mentor for Rana when she first arrived here in 2010. We shared a common graduate program and a concentration in archival studies, though I graduated more than a decade before she started her professional archival education. My job is no longer strictly archival, so I've found her professional collegiality quite stimulating over the years as I attempt to keep as current as possible with issues involving archives and special collections programs. She will turn 37 this year, and my hope is that she will soon start thinking about her potential for a job in management of a special collections or university library. Her leaving our organization would be a big loss, but she has a lot of energy and vision to contribute and I hope she at least entertains the possibility.

Rana's educational background is in political science and history, and she taught elementary school for a few years prior to her professional graduate program, completing a master's degree in contemporary Middle Eastern history during that period. We're quite lucky to have her here, as her knowledge of Middle Eastern studies allows her to spend a small amount of her time developing the library's general collection of print materials on the contemporary Middle East, which aren't part of special collections, or of national significance, but are an important resource for faculty here across a number of disciplines.

Rana's first job out of her graduate program was a three-year stint processing backlogged archival collections at a prestigious East Coast university. At that point, there were frequently good entry-level positions for archivists in special collections, funded by special project grants, especially between 2006 and the end of the decade when there was a real focus on addressing backlogs. Some institutions failed to capitalize on these grants to develop procedures that streamlined and clarified their decision-making procedures for archival processing, so backlogs continue to plague some repositories today. Unfortunately, some special collections directors back in the first decade of the twenty-first century just could not grapple with the issues that create backlogs and were unable to help their entry-level project archivists find an institutionally satisfying compromise between processing at higher levels and the item-level preservation work typically demanded in special collections repositories in the late twentieth century. ${ }^{5}$ Rana, luckily, landed a first job at a place with a supportive, engaged library director and a forward-looking special collections head.

5. For more information on these tensions, see the path-breaking article by Mark A. Greene and Dennis Meissner, "More Product, Less Process: Pragmatically Revamping Traditional Processing Approaches to Deal with Late 20th-Century Collections," forthcoming in American Archivist. A Web-accessible preprint of the article was available on Aug, 28, 2005 at http://ahc.uwyo.edu/documents/faculty/ greene/papers/ Greene-Meissner.pdf. 
They based processing decision-making and procedures on evolving national standards and worked collaboratively within the national special collections community in innovative and generalizable ways. ${ }^{6}$ This appears to have helped curators at that university library to make decisions regarding their collections in the context of the larger institutional picture, and as a result, they are frequently held up as a model for efficient collection management. She and a colleague, with whom she worked on a professional organization committee, published an influential article in a national journal analyzing and documenting a set of cross-institutional decision-making points they had developed.

I consider us quite fortunate to have attracted Rana after she finished her threeyear grant-funded backlog project. Her job here has never been directly involved in archival processing, something with which she has told me on numerous occasions she has had enough experience. Nonetheless, she brings a wealth of practical knowledge to the table when this topic is discussed. She was an important contributor to the library's decision a few years ago to apply standards for archival control beyond the confines of special collections, something necessitated by the rapidly increasing onslaught of information resources in electronic formats over the course of the past decade or so. Rana realized fairly quickly when she got here in 2010 that the scope of regionally significant digital materials that we should be identifying and collecting was beyond the technical and staffing resources of the special collections department. Both she and our head of special collections have been critical in working with our library director, information systems department, and the librarywide collection development group to plan for more distributed collecting of this material. They also have addressed a host of technical issues related to controlling, describing, providing access to, and preserving these unique information resources. This effort has helped to raise the university's public profile through the library's leadership role in the community. With Rana as a critically important contributor, we have worked with other local heritage and educational institutions to develop documentation and preservation strategies that ensure the long-term survival and accessibility of all kinds of digitally created resources documenting the individuals, communities, and businesses that help to define our region.

As one example of this work, Rana started working in 2014 or so with two local museums to expand their special collecting events to include contemporary digital still and video images, in addition to the old photographs and printed ephemera

6. As a present-day example, Christine Weideman (Yale University), Donna McCrea (University of Montana), and Mike Strom (Texas Christian University) presented an excellent Society of American Archivists (69th annual meeting: New Orleans, Louisiana, 19 Aug. 2005) conference session detailing three different case study applications of the recommendations from the Greene-Meissner article. See the online program at http:/ / www.archivists.org/conference/neworleans2005/no2005prog-Session. asp?event $=1489$. Accessed on 28 August 2005. 
usually brought in by community members. In the new infrastructure supporting the collection of born-digital material, the digital content gets described after copying by a group of museum volunteers using a manual that Rana helped to write. The library then harvests the descriptive metadata and content files from an Open Archives Initiative data provider that the library works with the museums to maintain. We store the digital objects in our institutional repository to ensure long-term preservation and access. Although the items do not live physically in our special collections department, public access to it and a wealth of other materials in our regional history collections is provided through the department's local history portal, one of the university's most frequently used Web sites. None of this would likely have happened without leadership and vision from special collections.

Rana also brought along from her graduate student days an interest in the documentary significance of blogs and the technical issues of using Web archiving techniques to capture them as historically significant information resources. In 2010 when she arrived, one of the first projects she organized, in conjunction with several collection development specialists and the information systems department, was appraising, identifying, and prototyping the archiving of several regionally significant blogs. As a result, we now have a quite sophisticated program of regional blog capture that has been gaining national significance over the course of the past nine years. One of the things I've come to admire about Rana is her ability to communicate with programmers. Even though she doesn't program herself, she's quite comfortable writing general specifications for software and algorithms outlining the steps required of a computer-assisted process.

But I'm afraid I'm making it sound as though she doesn't spend much time on the public service side of her job, and that couldn't be farther from the truth. In 2015, during a large renovation of our graduate library building, a planning team developed a vision for integrating all reference points in the newly configured building, including special collections. Rana was quite surprised and reluctant to do so at first, but she participated actively in a series of brainstorming groups organized by the library administration and sought out information from other institutions that have taken this integrationist approach to special collections reference services. In the end, I think she had a tremendous impact on making a smooth and successful transition to a more institutionally holistic model of reference. There is still a supervised reading room for rare and unique physical materials that is highly visible within the main reference area, but we've been successful at not tying up professional staff time with the monitoring, and the engagement with the broader library reference operation has paid off in dramatically extended hours for special collections access. Rana and the head of general reference got some local funding to design a year-long, multifaceted evaluation to assess the impact and effective- 
ness of the new reference services configuration, the results of which were quite encouraging and were published last year.

Rana and other professionals in special collections frequently provide research consultations for the collections that fall within their purview. She also does what I consider an amazing amount of teaching, seeking to mine the regional history collections in innovative ways that help faculty from a variety of disciplines to engage undergraduate students in original research using primary sources, using both physical and digital manifestations. She also is the central point for coordinating research visits by scholars from outside our area, whose in-person use of our collections has increased steadily during Rana's ten years here. All in all, I'd say that in terms of public services, our special collections staff, and especially Rana, is well integrated into the public services of the larger library in ways that seem to benefit our end users and increase their satisfaction with the services provided by the library.

So that is Rana. Anyone who knows me will not be fooled and will see in her shadings of many of my own professional interests. I also have attempted to capture in her experiences some of the technological issues that I deal with in my position at CDL, which isn't a special collections environment but frequently intersects with a variety of special collections issues. In taking a persona-based approach to developing several key archetypes for future special collections professionals, individual contributions to the composite persona will likely be self-reflective in this way. Nonetheless, having a fictional character and some guidelines about topics to cover (professional training and background, job responsibilities) and those to avoid (family background, marital status, hobbies) makes this exercise a more liberating and creative one, which seems important in trying to get a focus on a composite, collective vision of a special collections professional twenty or so years on and the kinds of skills needed to nudge us in that direction.

I also should be very clear that Rana would not be the persona but, rather, an individual contribution to a persona, someone who takes the place of having real end users of a product or service from whom we might gather data. None of us are special collections professionals in the year 2020, but I'd like to suggest that most of us could dream up a Rana who sums up in a couple of succinct pages the kind of person we'd like to work with if we're still around at that point, a colleague to help shape the kind of special collections environment in which we could see ourselves working in 2020.

One real challenge in using an approach such as this to assist in discovering education needs for special collections professionals is to determine the broad archetypal 
roles the personas, derived from individual contributions such as Rana, need to represent. Will special collections-or, for that matter, academic libraries in general-still be populated by roughly the same cast of characters in 2020 as they are in 2005? What combination of four or five personas would best represent the range of expertise needed in an academic special collections repository in 2020, and how will that be impacted by specifics such as the configuration of academic library departments and services at that point? Rana, as many will have noticed, is decidedly not someone who deals with rare book collections, though fleshing out her public services role in a bit more detail might surface some aspect of that. She also is not a manager responsible for the financial and personnel affairs of the department in which she works. In these ways, she reflects my own experience and perspectives on special collections. A set of personas, such as the one of which Rana might become a composite part, would be needed to account broadly, but comprehensively, for all the specializations and situations we can think of to hang on an envisioned special collections repository in 2020.

I think many recently minted special collections professionals—such as myself after little more than a decade of professional work — can attest to the fact that getting a good education for a career in academic special collections can be quite a challenge. Much of the real, practical training happens in internship settings, which can be spotty and idiosyncratic at best. Standards such as the Society of American Archivists' Guidelines for a Program in Archival Studies ${ }^{7}$ are useful, but it is difficult as a prospective student, in the absence of some kind of an accreditation or rating system, to judge from a specific program's promotional material just how successfully it meets such guidelines. Rare Book $\mathrm{School}^{8}$ is a fantastic model for concentrated professional educational opportunities, but as the recent Association for Research Libraries Special Collections Task Force White Paper on Education highlighted, it is worrisome that something on which so many institutions rely is precariously dependent on the dedication of one person and the good graces of a single institution. ${ }^{9}$ Furthermore, it is difficult to imagine the infrastructure that would be required to create an RBS equivalent for the messy, increasingly complex world of archival records and the processes necessary to bring them under physical and intellectual control.

7. Available at http://www.archivists.org/prof-education/ed_guidelines.asp. Accessed on 28 August 2005.

8. See http:/ / www.virginia.edu/oldbooks / for more information. Accessed on 28 August 2005.

9. Additional details about the work of, and reports produced by, this task force, including the White Paper on Education, is available at http://www.arl.org/collect/spcoll/index.html. Accessed on 28 August 2005. 
Nonetheless, the work of delineating core competencies for special collections professionals is important, especially in a time when the role and configurations of many academic special collections may be changing. The role of an approach such as the use of personas should be considered as a possible means of ensuring that the resulting competencies broadly reflect the needs of special collections for creative, visionary talent. Our successors must be capable of responding to dynamic forces in our information environment and carrying forward the legacy of powerful, engaged special collections programs in a variety of college and university settings.

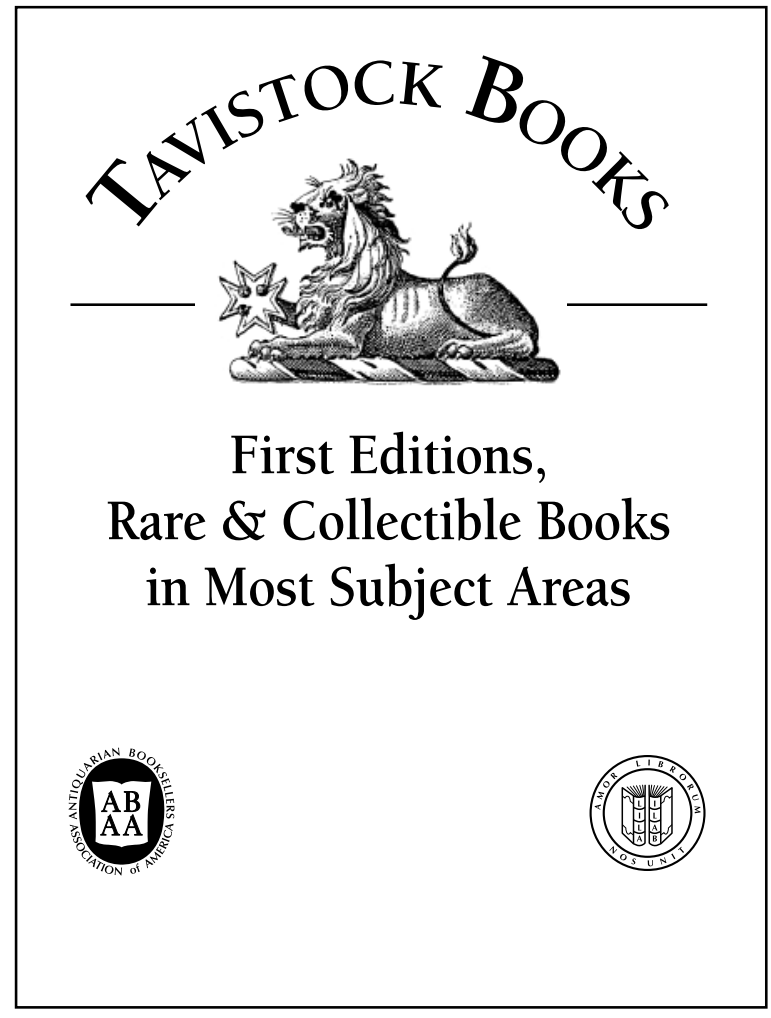

